\title{
Quality characteristics of Yakju containing pretreated lotus leaves
}

\author{
Jeong-Sil Choi, Soo-Hwan Yeo, Han-Seok Choi, Seok-Tae Jeong* \\ Fermented Food Science Division, National Institute of Agricultural Science, Wanju 55365, Korea
}

\section{전처리를 달리한 연잎을 이용한 약주의 품질특성}

\author{
최정실 · 여수환 · 최한석 · 정석태* \\ 국립농업과학원 발효식품과
}

\begin{abstract}
This study aimed to find an effective preservation method of lotus leaves for the preparation of lotus-leaf Yakju throughout the year. The characteristics of Yakju containing lotus leaves pretreated by blanching, steaming, roasting, and drying were investigated in this study. The chemical properties of Yakju (pH, amino acidity, alcohol content, and volatile acid content) were significantly different for all treatments, except for the total acid content. The polyphenol content ranging from 315.89 to $462.63 \mathrm{ppm}(\mathbf{p}<0.05)$ was significantly different depending on pretreatment method L color value for Yakju was not significantly different all treatments, while a value was significantly different in Yakju containing frozen stored leaves after pretreatment. The b value was lowest for the blanching treatment, and was significantly different for all treatments. Among the organic acids present in Yakju, the oxalic, citric, and malic acid contents were significantly different for all treatments. In sensory evaluation, lotus-leaf Yakjus containing fresh leaves and dried leaves were preferred to the others in color and flavor among Yakjus prepared with lotus leaves before cold storage. However, among the Yakjus prepared with lotus leaves after cold storage, that containing blanched leaves was preferred to the others in terms of flavor, taste, and overall acceptability.
\end{abstract}

Key words : Yakju, lotus leaf, pretreated, quality

\section{서 론}

우리나라의 전통주에는 양조방법에 따라 수백 여 종의 다양한 술이 존재한다(1). 이 중 약주는 찹쌀이나 멥쌀을 원료로 하고 누룩으로 발효시켜 만든 술로서 알코올 농도가 $13 \%$ 이하로 맑게 거른 술이다(2). 약주는 탁주와 마찬가지 로 담금 후에도 누룩 중의 미생물에 의한 효소작용에 의해 생성되는 당분, 아미노산 등의 맛 성분과 휘발성 풍미성분 및 생리활성 물질 등이 함유되어 있다(2-4). 최근에 건강에 관한 관심이 높아지면서 약재의 잎이나 뿌리 등을 부 재료 로 사용한 건강기능성 주류개발이 활발히 이루어지고 있는

*Corresponding author. E-mail : jst@korea.kr

Phone : 82-63-238-3615, Fax : 82-63-238-3843

Received 1 December 2015; Revised 4 February 2016; Accepted 5 February 2016

Copyright (c) The Korean Society of Food Preservation. All rights reserved.
데(4) 이러한 부 재료는 약주의 발효과정 중에 용출되어 건강기능성 향상에 도움을 줄 수 있는 것으로 보고되었다 (3).

연(Nelumbo nucifera)은 수련과 다년생 수초로 인도, 중 국, 일본, 한국 및 북호주 등에 널리 분포되어 있다. 중국에 서는 연을 불로식(不老食)으로 취급하여 약재로 이용해 왔 으며 우리나라에서는 연잎을 비롯한 연근, 연꽃, 연심, 연자 육 등을 식용 및 약용으로 널리 사용하고 있다(5,6). 이 중에 연근과 연잎에는 alkaloid 성분, 항산화 비타민 및 플라보노 이드(flavonoide) 등 다양한 생리활성 성분을 함유하고 있다 $(7,8)$. 연잎으로 만든 제품으로는 연엽주, 연잎차 등이 있으 며 연잎의 기능성에 대한 연구로는 연잎의 항산화(9), 연잎 의 지방축적 억제 효과 $(10,11)$, 연잎 추출물의 항균효과(12) 등이 있다. 또한, 최근에는 연잎을 이용한 다양한 조리방법 등이 수행되고 있는 것으로 보고되었다 $(13,14)$.

이같이 연잎은 유용한 재료로 활용되고 있으며, 향후 연 재배 면적도 더욱 더 확대될 것으로 추정된다. 이에 따라 
연의 이용성 증대를 통한 새로운 수요 창출이 요구되고 있다. 그러나 연잎의 생산 시기는 한정되어 있어 장기간 보관할 수 있는 기술이 요구되며 연잎의 활용성 연구가 더욱 필요할 것으로 생각된다.

신선농산물은 수확 후에도 호흡, 증산작용과 같은 생리 활동을 계속하므로 저장이나 유통 중에 품질이 변하게 된다 (15). 이에 신선농산물의 저장성을 높이는 전처리 기술로 데치기, 덖음, 건조 등이 사용된다. 곡물이나 채소를 저장하 기 전에 짧은 시간 고온 가열하여 품질 저하에 관련된 효소 를 불활성화함으로써 저장성을 높이는 전처리 기술인 데치 기와(10) 차 제조시 생잎 특유의 풋내, 쓴맛, 떫은맛과 같은 바람직하지 않은 향미를 감소시키고 가열에 의해 새로운 향미를 생성시켜 기호성을 증진시키는데 이용되는 덖음처 리(17), 즉 덖어서 익히는 공정으로 탈수 및 건조하는 방법 이다(18). 또한, 건조는 수분을 제거하는 조작으로 미생물 이나 효소에 의한 변질을 방지함으로써 저장성을 향상시키 는 기술로 방법은 다양하나 열 풍건조가 주를 이룬다(19). 스팀처리는 갈변을 일으키는 효소를 불활성시키고 조직을 부드럽게 하며 생잎의 풋내를 제거하기 위해서 한다(18).

본 연구에서는 약주의 연중 생산을 위해 전처리한 연잎 을 활용한 약주의 품질특성을 파악함으로써 연잎약주 제조 에 적합한 연잎의 전처리방법을 알아보고자 하였다.

\section{재료 및 방법}

\section{실험재료}

본 실험에 사용한 연잎은 백련잎으로 경기도 시흥의 관 곡지에서 8월 중순에 수확한 것을 사용하였다. 약주 제조를 위한 쌀은 경기도 수원에서 생산된 추청품종을 사용하였으 며, 발효제로는 개량누룩(1000sp/g, Korea enzyme, Hwaseong, Korea)을, 효모는 Saccaromyces cerevisiae( $\mathrm{La}$ Parisienne S.I. Lesaffre, France)를 사용하였다.

\section{연잎의 처리}

연잎은 크게 2 가지로 분류하여 처리하였다. 첫째는 연잎 을 전처리 후 냉동보관 $\left(-10^{\circ} \mathrm{C}\right)$ 하다가 사용, 둘째는 연잎을 냉동보관 후 처리를 하여 사용하는 방법이다. 첫 번째 전처 리 방법으로는 연잎을 흐르는 물에 여러 번 세척 후 물기를 제거하고 연잎을 $1 \sim 2 \mathrm{~cm}$ 로 세절하여 각각 데치기, 덖음, 건조처리를 하였다. 데치기 처리는 꼻는 물에서 20 초간 처 리 후 건져내어 상온에서 냉각하였고, 덖음 처리는 약 $120 ~ 150^{\circ} \mathrm{C}$ 에서 3 분간 처리 후 상온에서 냉각하였다. 건조 처리는 $40^{\circ} \mathrm{C}$ 의 건조기에서 12 시간 간격으로 뒤집어 주면서 48시간 건조시켰다. 이때 처리하지 않은 것을 대조구로 하 였다. 이렇게 처리한 시료는 모두 플라스틱 지퍼백(PE 0.1 $\mathrm{mm})$ 에 넣어 $-10^{\circ} \mathrm{C}$ 에서 냉동보관(90일)하면서 사용하였다.
두 번째 방법으로는 1 2 cm로 세절한 연잎을 냉동저장 $\left(-10^{\circ} \mathrm{C}, 90\right.$ 일)한 후 술 담금 시 데치거나 덖거나 스팀처리 등 처리하여 사용하였다. 데치기나 덖음은 처리하지 않고 보관한 냉동연잎을 위와 같은 방법으로 처리하여 사용하였 고 스팀처리는 끓는 수증기를 30 초간 처리한 다음 상온에 서 냉각 후 사용하였다.

\section{약주 담금}

연잎약주는 쌀 $1 \mathrm{~kg}$ 에 대하여 개량누룩 $30 \mathrm{~g}$, 효모 0.6 $\mathrm{g}$, 물 $2 \mathrm{~L}$ 로 1 단 담금하여 $25^{\circ} \mathrm{C}$ incubator(VS-1203PFHLN, Vision Scientific, Co., Ltd., Daejeon, Korea)에서 발효하였 다. 이틀 후, 냉동전 및 냉동후 처리방법을 달리하여 제조한 연 잎을 담금 총량에 대하여 생잎기준 $5 \%$ 넣어 총 10 일간 발효시켰다. 이렇게 하여 연잎약주가 완성이 되면 40 60 mesh 정도의 면포에 넣고 압착하여 여과하여 제조하였다.

\section{$\mathrm{pH}$ 및 총산}

연잎약주의 $\mathrm{pH}$ 는 $\mathrm{pH}$ meter(Beckman, Model 115PD, Istek Co., Seoul, Korea)로 측정하였고, 총산은 연잎약주 시료 $10 \mathrm{~mL}$ 를 삼각플라스크에 넣고 $0.1 \mathrm{~N} \mathrm{NaOH}$ 로 $\mathrm{pH}$ 8.2 가 될 때까지 중화적정하여 그 값을 젖산으로 환산하여 나타내었다.

\section{알코올 함량}

연잎약주 시료 $100 \mathrm{~mL}$ 를 증류 및 냉각 장치에 연결하여 가열하여 증류액을 약 $80 \mathrm{~mL}$ 이상 받고 $100 \mathrm{~mL}$ 까지 증류수 로 정용하였다. 증류액을 잘 혼합한 다음 주정계를 사용하 여 눈금을 읽고 주정분 온도 환산표(20)로서 $15^{\circ} \mathrm{C}$ 로 보정하 여 알코올 농도(\%,v/v)함량으로 나타내었다.

\section{휘발산 정량}

연잎약주의 알코올 분석용 증류액 $30 \mathrm{~mL}$ 를 취하여 삼각 플라스크에 넣고 $0.01 \mathrm{~N} \mathrm{NaOH}$ 로 $\mathrm{pH}$ 8.2가 될 때까지 중화 적정하여 소비된 $0.01 \mathrm{~N} \mathrm{NaOH}$ 을 초산으로 환산하여 표시 하였다(21).

\section{아미노산도}

연잎약주의 아미노산도는 시료 $10 \mathrm{~mL}$ 를 $100 \mathrm{~mL}$ 삼각플 라스크에 취한 다음, 페놀프탈레인 지시약 2 3방울을 가하 여 $0.1 \mathrm{~N} \mathrm{NaOH}$ 용액으로 엷은 분홍색이 나올 때까지 적정 한다. 여기에 중성포르말린 용액 $5 \mathrm{~mL}$ 를 넣어 원래의 색이 나오게 한다. 다시 $0.1 \mathrm{~N} \mathrm{NaOH}$ 용액으로 엷은 분홍색이 나올 때까지 적정하여 소비된 용액의 양을 아미노산도로 표시하였다(20).

\section{총 폴리페놀 함량}

Jung 등(22)의 방법에 따라 연잎약주 시료 $1 \mathrm{~mL}$ 에 0.2 
M sodium acetate( $\mathrm{pH} 1.0)$ 완충용액 $9 \mathrm{~mL}$ 를 넣어 $2 \mathrm{~mm}$ cell에 담고 $280 \mathrm{~nm}$ 에서 UV-visible spectrophotometer (JP/U-2000 spectrophotometer, Hitachi Ltd, Tokyo, Japan)로 측정하였다. 총 폴리페놀 함량은 gallic acid 표준용액 검량 선으로 환산하여 나타내었다.

\section{색 도}

연잎약주의 색도는 색차계(Hunterlab Ultra Scan Pro, Reston, VA, USA)를 이용하여 명도(lightness, L), 적색도 (redness, a) 및 황색도(yellowness, b)값을 측정하여 나타내 었다.

\section{유기산}

연잎약주 $1 \mathrm{~mL}$ 를 증류수로 5 배 희석하여 고분자물질과 색소를 제거하기 위하여 Sep-pak(Oasis HLB $60 \mu \mathrm{m}$ Catridge, Waters, Milford, Massachusetts, USA) 및 membrane filter(nylon, $0.22 \mu \mathrm{m}$, Merck Millipore Co. Damstadt, Germany)로 여과하여 HPLC(LC-20A, Shimazu, Kyoto, Japan)를 이용하였으며 post column방법을 사용하여 분석하였다. 분석용 column은 $\mathrm{KC}-811(300 \mathrm{~mm} \times 8 \mathrm{~mm}$, Shodex, Tokyo, Japan)을 사용하였으며, 이동상은 $3 \mathrm{mM}$ perchloric acid로 유속 $0.8 \mathrm{~mL} / \mathrm{min}$, column oven 온도 $63^{\circ} \mathrm{C}$, injection volume $10 \mu \mathrm{L}$ 로 하였다. 분리물은 반응용액 $(0.2$ $\mathrm{mM}$ bromothymol blue, $15 \mathrm{mM} \mathrm{Na}_{2} \mathrm{HPO}_{4}, 2 \mathrm{mM} \mathrm{NaOH}$ )과 반응한 후 UV $440 \mathrm{~nm}$ 에서 검출하였다. 이때 반응용액의 flow rate는 $1.0 \mathrm{~mL} / \mathrm{min}$, 반응온도는 $30^{\circ} \mathrm{C}$ 로 하였다.
를 수행하고 있는 전문 연구원 10 명을 대상으로 연잎약주 의 기호도에 대하여 조사하였으며, 각 처리별 색, 향, 맛 및 전반적인 기호도에 대하여 우수하다고 판단되는 처리구 2 개를 선택하게 하였다. 각 처리별 기호성은 총 선택 가능수 (20회)에 대한 선택횟수를 백분율로 나타내는 다중응답 빈 도분석한 결과를 그래프로 표현하였다.

\section{통계처리}

모든 데이터는 3회 반복 측정하였으며, 평균표준편차 로 표시하였다. 통계분석은 SPSS 프로그램 12.0 버전을 이 용하여 일원분산분석(One-way ANOVA)과 시료간 유의적 인 차이가 있을 경우, $a=0.05$ 수준에서 Duncan의 다중범위 검정을 실시하였다.

\section{결과 및 고찰}

\section{전처리 방법별 약주의 품질특성}

전처리 방법별 연잎으로 제조한 약주의 일반적인 품질특 성은 Table 1 과 같다. 술덧의 $\mathrm{pH}$ 는 발효상태를 파악하는 중요한 요소 중의 하나로 $\mathrm{pH}$ 가 높을 경우에는 외부의 잡균 에 의해 오염이 되기 쉬우며, $\mathrm{pH}$ 가 너무 낮게 되면 강한 산미로 인해 주류의 품질이 악화될 수 있는 요인이 될 수 있다(23). 냉동 전·후에 처리를 달리한 연잎약주의 $\mathrm{pH}$ 는 4.66 4.77 사이로 냉동저장 생잎을 가지고 담근 약주에서 $\mathrm{pH}$ 가 4.77로 가장 높고 대조구와 다른 처리구간 유의적인

Table 1. Properties of Yakju containing lotus leaves pretreated differently before and after cold storage

\begin{tabular}{|c|c|c|c|c|c|c|}
\hline & & $\mathrm{pH}$ & $\begin{array}{l}\text { Total acid } \\
(\%, \mathrm{w} / \mathrm{v})\end{array}$ & $\begin{array}{c}\text { Amino acidity } \\
(\mathrm{mL})\end{array}$ & $\begin{array}{l}\text { Alcohol } \\
(\%, \mathrm{v} / \mathrm{v})\end{array}$ & Volatile acid $(\mathrm{mg} / \mathrm{L})$ \\
\hline \multirow{5}{*}{$\begin{array}{l}\text { Before } \\
\text { cold } \\
\text { storage }\end{array}$} & Fresh & $4.77 \pm 0.06^{1 / \mathrm{a} 2)}$ & $0.57 \pm 0.02$ & $4.45 \pm 0.01^{\mathrm{a}}$ & $16.60 \pm 0.10^{b}$ & $41.93 \pm 1.47^{\mathrm{a}}$ \\
\hline & Blanching & $4.66 \pm 0.01^{b}$ & $0.58 \pm 0.01$ & $4.28 \pm 0.11^{\mathrm{b}}$ & $16.27 \pm 0.12^{\mathrm{b}}$ & $33.47 \pm 0.61^{c}$ \\
\hline & Roasting & $4.67 \pm 0.01^{b}$ & $0.59 \pm 0.01$ & $4.01 \pm 0.11^{\mathrm{c}}$ & $17.00 \pm 0.30^{\mathrm{a}}$ & $41.87 \pm 0.81^{\mathrm{a}}$ \\
\hline & Drying & $4.69 \pm 0.01^{\mathrm{b}}$ & $0.57 \pm 0.02$ & $4.58 \pm 0.06^{\mathrm{a}}$ & $17.27 \pm 0.12^{\mathrm{a}}$ & $38.13 \pm 2.50^{\mathrm{b}}$ \\
\hline & F-value & $7.436^{* * 3)}$ & $1.581^{\mathrm{NS} 4)}$ & $28.152^{* \star *}$ & $18.351^{* \star}$ & $20.353^{* * *}$ \\
\hline \multirow{5}{*}{$\begin{array}{l}\text { After } \\
\text { cold } \\
\text { storage }\end{array}$} & Fresh & $4.77 \pm 0.03^{\mathrm{a}}$ & $0.59 \pm 0.00$ & $4.38 \pm 0.02^{\mathrm{a}}$ & $16.67 \pm 0.29^{\mathrm{ab}}$ & $44.93 \pm 6.73^{\mathrm{a}}$ \\
\hline & Blanching & $4.66 \pm 0.02^{\mathrm{b}}$ & $0.59 \pm 0.00$ & $4.11 \pm 0.15^{\mathrm{c}}$ & $15.83 \pm 0.35^{c}$ & $34.67 \pm 1.55^{b}$ \\
\hline & Steaming & $4.69 \pm 0.01^{b}$ & $0.59 \pm 0.01$ & $4.18 \pm 0.02^{b c}$ & $17.20 \pm 0.40^{\mathrm{a}}$ & $46.73 \pm 2.76^{\mathrm{a}}$ \\
\hline & Roasting & $4.74 \pm 0.02^{\mathrm{a}}$ & $0.58 \pm 0.01$ & $4.29 \pm 0.05^{\mathrm{ab}}$ & $16.27 \pm 0.06^{\mathrm{bc}}$ & $43.53 \pm 3.60^{\mathrm{a}}$ \\
\hline & F-value & $18.515^{* k}$ & $0.667^{\mathrm{NS}}$ & $6.418^{* *}$ & $10.988^{* *}$ & $5.053^{* *}$ \\
\hline
\end{tabular}

\footnotetext{
1) mean \pm SD $(n=3)$.

${ }^{2)}$ Means in a column by different superscripts are significantly different at $\mathrm{p}<0.05$ significance level by Duncan's multiple range test. $\left.{ }^{3}\right)^{*}<0.05, \quad{ }^{* *}<0.01,{ }^{* * *} \mathrm{p}<0.001$.

4) $\mathrm{S}$ means no significance.
}

\section{기호도 조사}

냉동 전.후 처리 방법에 따른 약주의 기호적 특징을 알아 보기 위해 국립농업과학원 발효식품과에서 주류관련 연구
차이를 나타냈다. 반면, 약주 속의 유기산의 함량과 아미노 산 함량에 따라 달라지는 총산의 경우(24) 처리구간에 유의 적인 차이를 나타내지 않았다. 이것은 미생물의 발효에 의 
해 생성되는 유기산과 아미노산 함량 등이 이 처리에 의해 아무런 영향을 주지 못했다고 판단된다. 아미노산도의 경 우, 냉동전 건조 처리한 연잎 약주가 가장 높은 $4.58(\mathrm{~mL})$ 을 나타냈고 처리구간에 유의적인 차이가 있었다 $(\mathrm{p}<0.05)$. 특 히 냉동전 데치기 처리한 연잎 약주나 냉동전 덖음 처리 연잎 약주와는 유의적인 차이를 보였다. 아미노산은 술의 주원료인 쌀과 누룩이 발효 과정 중에 단백질 분해 효소 작용으로 생성되어 발효주의 감칠맛에 영향을 주는 물질로 발효기간이 경과함에 따라 증가되는 것으로 보고된 바 있다 (23). 아미노산도는 발효가 완료된 술에 유리된 아미노산이 많다고 보고 있는데(25) 냉동 전·후에 처리를 달리한 연잎 약주에 전처리 종류에 따라 아미노산도의 차이를 보인 것은 단백질 함량이 $16.9 \%$ 인 연잎 $(26)$ 이 전처리에 따른 소실 여부나 미생물이 내는 단백질 분해 효소에 영향을 받은 것으로 판단된다. 알코올 함량은 주류의 품질을 결정하는 중요한 성분으로(23) 처리구에 따라 16.3 17.3(\%, v/v)으로 일반 약주와 비슷하며 특히나 냉동전 덖음이나 건조한 처리 구에서 알코올이 높게 나타났다. 반면, 냉동전 무처리구나 데치기 처리구는 다소 낮게 나타났다. 냉동후 처리한 연잎 약주의 경우는 생잎이나 스팀처리한 구가 알코올 함량이 다소 높게 나타났다. 이것은 처리에 따라서 연잎의 유기산 이나 당이 달라짐으로써 알코올 생성에 영향을 주었을 것으 로 추측된다. 약주에 있어서 휘발산은 기호성에 바람직하 지 않은 성분으로 과량으로 함유되어 있으면 발효 중에 초산 생성균에 의한 이상발효가 진행되었음을 나타낸다 (27). 연잎약주의 휘발산 함량은 처리 방법에 따라 $33.47 \sim 6.73 \mathrm{ppm}$ 으로, Kong 등이 보고한(27) 연잎 처리방 법에 따른 약주의 휘발산 함량보다 (302 466 ppm) 다소 낮은 특징을 보였다.

\section{전처리 방법별 약주의 총폴리페놀 및 색도 특성}

냉동 전·후에 처리를 달리한 연잎약주의 폴리페놀 함량 은 Table 2 와 같다. 폴리페놀은 항산화력과 항돌연변이 효 과, 항암효과를 가지고 있어 활성산소와 킬레이트 금속이 온을 없애는 역할을 한다(28). 냉동 전.후 모든 처리구간에 폴리페놀 함량에 유의적인 차이가 나타났다 $(\mathrm{p}<0.05)$. 전체 적으로 $315.89 \pm 28.08 \sim 462.63 \pm 13.00 \mathrm{ppm}$ 의 범위를 보였다. 시판 연엽주의 폴리페놀 함량을 구한 결과, $1063 \mathrm{ppm}$ 으로 높은 수치의 결과가 나왔다(28). 이에 비하면 다소 적은 양인 폴리페놀 함량은 $315.9 \sim 428 \mathrm{ppm}$ 의 범위를 보여 처리 간에 다소 차이가 있는 것으로 판단되는데, 냉동 전.후 모두 데치기 처리는 낮은 반면 덖음처리는 높은 것으로 나타났 다. 이것은 처리에 따라 약주 품질에 영향을 미친 것으로 판단된다. 연잎의 처리 방법별 약주의 색도에 있어서, 데치 기 처리가 황색도 $\mathrm{b}$ 값이 가장 낮아 연잎의 데치기 처리가 약주 색의 갈변을 방지할 수 있는 것으로 판단된다. 각 처리 별 명도 값은 큰 차이가 없었으나 적색도와 황색도는 큰
차이를 보였다. 연잎 약주의 색에 있어서 육안으로 관찰시 덖음 처리가 진한 반면 스팀처리는 엷은 색상을 보였으나, 기계적인 색도 분석에서는 큰 차이를 보이지 않았다. 갈변 현상은 연잎에 있는 폴리페놀 물질이 폴리페놀산화효소에 의해 산화됨으로 갈색을 띠는 것으로 추측된다(23).

Table 2. Polyphenol contents and Hunter's color values of Yakju containing lotus leaves pretreated differently before and after cold storage

\begin{tabular}{|c|c|c|c|c|c|}
\hline \multirow{2}{*}{\multicolumn{2}{|c|}{$\begin{array}{l}\text { Pretreatment } \\
\text { methods }\end{array}$}} & \multirow{2}{*}{$\begin{array}{l}\text { Polyphenol } \\
\text { (ppm) }\end{array}$} & \multicolumn{3}{|c|}{ Hunter's color value } \\
\hline & & & $\mathrm{L}$ & $\mathrm{a}$ & $\mathrm{b}$ \\
\hline \multirow{5}{*}{$\begin{array}{l}\text { Before } \\
\text { cold } \\
\text { storage }\end{array}$} & Fresh & $438.21 \pm 9.06^{1132)}$ & $91.73 \pm 1.18$ & $-0.14 \pm 0.24^{\mathrm{ab}}$ & $11.23 \pm 0.80^{\mathrm{a}}$ \\
\hline & Blanching & $387.21 \pm 10.69^{c}$ & $93.77 \pm 0.32$ & $-1.16 \pm 0.03^{\mathrm{c}}$ & $8.25 \pm 0.19^{c}$ \\
\hline & Roasting & $462.63 \pm 13.00^{\mathrm{a}}$ & $92.34 \pm 0.51$ & $-0.46 \pm 0.14^{b}$ & $11.40 \pm 0.21^{\mathrm{a}}$ \\
\hline & Drying & $429.02 \pm 4.58^{\mathrm{b}}$ & $92.83 \pm 0.91$ & $-0.05 \pm 0.34^{\mathrm{a}}$ & $10.00 \pm 0.56^{b}$ \\
\hline & F-value & $30.670^{* * 33)}$ & $3.513^{\mathrm{NS} 4)}$ & $14.763^{* *}$ & $23.552^{* * k}$ \\
\hline \multirow{5}{*}{$\begin{array}{l}\text { After } \\
\text { cold } \\
\text { storage }\end{array}$} & Fresh & $394.18 \pm 14.95^{\mathrm{a}}$ & $93.99 \pm 0.99$ & $-0.03 \pm 0.32$ & $9.59 \pm 0.26^{\mathrm{a}}$ \\
\hline & Blanching & $315.89 \pm 28.08^{b}$ & $94.35 \pm 0.99$ & $0.00 \pm 0.07$ & $7.30 \pm 0.43^{\mathrm{b}}$ \\
\hline & Steaming & $398.28 \pm 5.48^{\mathrm{a}}$ & $94.09 \pm 0.58$ & $-0.18 \pm 0.19$ & $9.43 \pm 0.57^{\mathrm{a}}$ \\
\hline & Roasting & $428.57 \pm 13.73^{\mathrm{a}}$ & $94.59 \pm 1.07$ & $-0.50 \pm 0.17$ & $9.54 \pm 0.37^{\mathrm{a}}$ \\
\hline & F-value & $22.528^{* k *}$ & $0.255^{\mathrm{NS}}$ & $3.589^{\mathrm{NS}}$ & $21.018^{* * *}$ \\
\hline
\end{tabular}

1) mean \pm SD ( $n=3)$.

${ }^{2)}$ Means in a column by different superscripts are significantly different at $p<0.05$ significance level by Duncan's multiple range test.

${ }^{3}{ }^{*}<0.05, \quad{ }^{* *} \mathrm{p}<0.01, \quad{ }^{* * *} \mathrm{p}<0.001$

4) $\mathrm{S}$ means no significance.

\section{전처리 방법별 약주의 유기산 함량 특성 및 기호도 평가}

대부분 효모의 대사로부터 생산되는(29) 유기산은 술에 있어서 상쾌한 맛을 내는 주체로 특히 citric acid 와 lactic acid 는 청량감을 주고 갈증을 해소해 주는 주요한 유기산이 다. 뿐만 아니라 유기산은 몸속의 각종 피로물질을 제거하 고 신진대사를 촉진시키는 기능을 한다고 한다(24). 연약주 의 유기산 분석 결과(Table 3), 양에서 약간의 차이는 있지만 처리방법에 상관없이 citric acid, lactic acid, succinic acid가 주요 유기산으로 확인되었고, lactic acid가 가장 많이 존재 하였다. 냉동전 처리 연잎 약주에서는 연잎의 처리 방법이 약주 발효 시 유기산 중에서 tartaric acid, succinic acid 및 lactic acid에는 영향을 미치지 않았다. 또한, 냉동후 처리한 연잎 약주에서는 tartaric acid, succinic acid 및 acetic acid 함량에는 유의적인 차이를 보이지 않았다. 냉동전·후 처리 방법에 따른 연잎약주의 기호도 평가는 선택율로 나타내었 다(Fig. 1). 냉동전 처리 연잎약주(A)의 경우, 색과 향에 있어 서 생잎과 건조처리구의 선택율이 각각 색은 $30 \%, 35 \%$, 향은 $30 \%, 30 \%$ 로 선호도가 높았다. 반면, 색에 있어서 덖음 처리 $(10 \%)$ 와 향에 있어서 데치기 처리(15\%)가 낮은 선택율 을 보였다. 색과 관련하여 냉동전 덖음 처리한 약주의 폴리 페놀 함량은 다른 처리구에 비해서 Table 2에서 보는 바와 
Table 3. Organic acid contents of Yakju containing lotus leaves pretreated differently before and after cold storage

\begin{tabular}{|c|c|c|c|c|c|c|c|c|}
\hline \multirow{2}{*}{\multicolumn{2}{|c|}{$\begin{array}{l}\text { Pretreatment } \\
\text { methods }\end{array}$}} & \multicolumn{7}{|c|}{ Organic acids (mg\%) } \\
\hline & & Oxalic & Citric & Tartaric & Malic & Succinic & Lactic & Acetic \\
\hline \multirow{5}{*}{$\begin{array}{l}\text { Before } \\
\text { cold } \\
\text { storage }\end{array}$} & Fresh & $9.10 \pm 0.97^{1 / 22)}$ & $69.85 \pm 2.35^{\mathrm{a}}$ & $2.60 \pm 0.39^{\mathrm{ab}}$ & $14.50 \pm 0.55^{b}$ & $91.05 \pm 2.57^{\mathrm{a}}$ & $98.73 \pm 4.49^{\mathrm{a}}$ & $7.43 \pm 0.48^{\mathrm{ab}}$ \\
\hline & Blanching & $4.55 \pm 0.48^{b}$ & $55.96 \pm 0.38^{\mathrm{b}}$ & $3.22 \pm 0.63^{\mathrm{a}}$ & $14.05 \pm 0.27^{\mathrm{b}}$ & $89.85 \pm 3.19^{\mathrm{a}}$ & $99.01 \pm 7.78^{\mathrm{a}}$ & $5.88 \pm 0.41^{\mathrm{c}}$ \\
\hline & Roasting & $9.87 \pm 0.65^{\mathrm{a}}$ & $69.72 \pm 1.59^{\mathrm{a}}$ & $2.59 \pm 0.55^{\mathrm{ab}}$ & $15.84 \pm 1.05^{\mathrm{a}}$ & $91.89 \pm 2.27^{a}$ & $96.70 \pm 4.80^{\mathrm{a}}$ & $6.67 \pm 0.62^{b c}$ \\
\hline & Drying & $6.12 \pm 1.24^{b}$ & $67.82 \pm 3.85^{\mathrm{a}}$ & $1.59 \pm 0.77^{\mathrm{b}}$ & $14.53 \pm 0.43^{b}$ & $93.48 \pm 3.26^{\mathrm{a}}$ & $101.64 \pm 2.03^{\mathrm{a}}$ & $7.57 \pm 0.14^{\mathrm{a}}$ \\
\hline & F-value & $23.917^{* \star 33)}$ & $23.151^{* * t}$ & $3.783^{\mathrm{NS4})}$ & $4.322^{* *}$ & $0.853^{\mathrm{NS}}$ & $0.458^{\mathrm{NS}}$ & $9.090^{* *}$ \\
\hline \multirow{5}{*}{$\begin{array}{l}\text { After } \\
\text { cold } \\
\text { storage }\end{array}$} & Fresh & $9.62 \pm 0.62^{\mathrm{a}}$ & $67.00 \pm 2.27^{\mathrm{a}}$ & $2.70 \pm 0.11^{\mathrm{ab}}$ & $15.10 \pm 0.50^{\mathrm{a}}$ & $88.67 \pm 2.47^{\mathrm{ab}}$ & $103.00 \pm 3.67^{\mathrm{a}}$ & $5.93 \pm 0.80^{\mathrm{ab}}$ \\
\hline & Blanching & $0 \pm 0^{c}$ & $50.96 \pm 0.98^{\mathrm{c}}$ & $3.16 \pm 0.25^{\mathrm{a}}$ & $12.96 \pm 0.54^{b}$ & $86.14 \pm 2.50^{b}$ & $98.48 \pm 3.76^{\mathrm{ab}}$ & $5.48 \pm 0.62^{b}$ \\
\hline & Steaming & $7.71 \pm 0.34^{b}$ & $61.34 \pm 1.05^{b}$ & $3.01 \pm 0.56^{\mathrm{a}}$ & $14.58 \pm 0.78^{\mathrm{a}}$ & $86.66 \pm 1.75^{b}$ & $103.92 \pm 2.65^{\mathrm{a}}$ & $5.59 \pm 0.13^{b}$ \\
\hline & Roasting & $8.88 \pm 1.00^{\mathrm{a}}$ & $68.88 \pm 1.68^{\mathrm{a}}$ & $2.34 \pm 0.19^{c}$ & $15.73 \pm 0.49^{\mathrm{a}}$ & $91.86 \pm 2.24^{\mathrm{a}}$ & $94.70 \pm 2.40^{b}$ & $6.83 \pm 0.42^{\mathrm{a}}$ \\
\hline & F-value & $158.824^{* k \star}$ & $77.915^{\text {ktk }}$ & $3.667^{\mathrm{NS}}$ & $12.153^{* \star}$ & $3.950^{\mathrm{NS}}$ & $5.435^{* *}$ & $3.090^{\mathrm{NS}}$ \\
\hline
\end{tabular}

${ }^{1)}$ mean $\pm \mathrm{SD}(\mathrm{n}=3)$

${ }^{2)}$ Means in a column by different superscripts are significantly different at $\mathrm{p}<0.05$ significance level by Duncan's multiple range test.

${ }^{3)^{*}} \mathrm{p}<0.05, \stackrel{* *}{\mathrm{p}}<0.01, \stackrel{* * *}{\mathrm{k}}<0.001$.

means no significance.

\section{A}

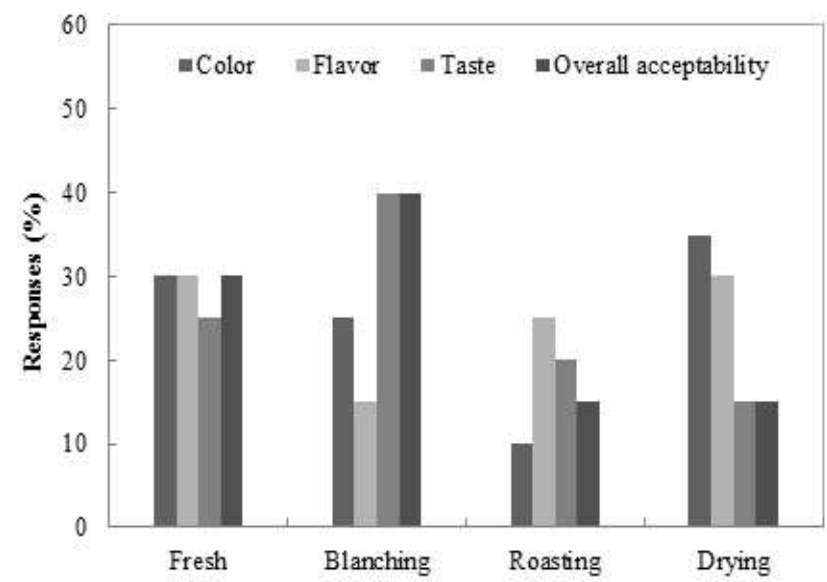

B

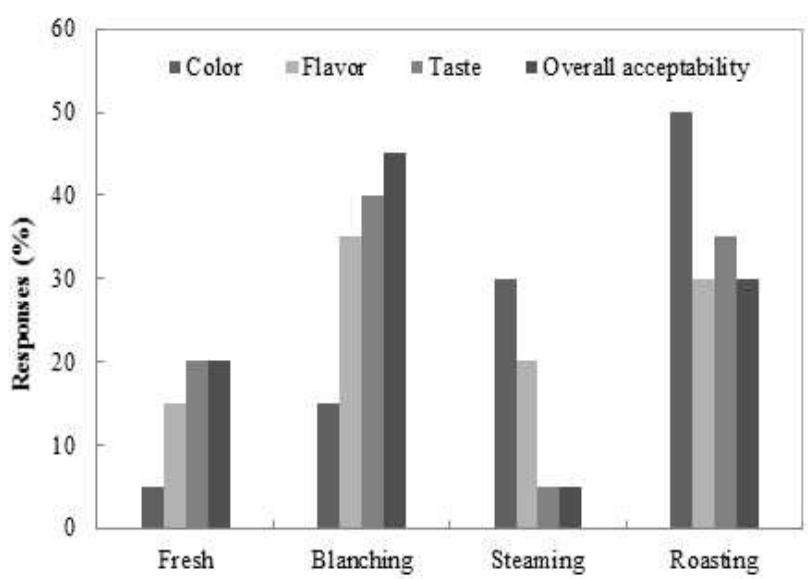

Fig. 1. Sensory evaluation (responses, \%) of Yakju containing lotus leaves pretreated differently before and after cold storage (A, before; $\mathrm{B}$, after).
같이, $462.63 \mathrm{ppm}$ 으로 가장 높은 수치를 보였고 또한, $\mathrm{b}$ 값도 가장 높은 수치를 보였으나 선호하는 색에는 영향을 미치지 않았다. 향에 있어서는 생잎이나 건조 처리구 약주에서 더 선호하는 것으로 나타났다. 맛이나 전반적인 기호도에 있 어서는 색과 향기의 결과와는 다르게, 데치기 처리가 높은 선택비율 $(40 \%)$ 을 보였는데 약주의 전반적인 기호도는 색 과 향기보다는 맛이 크게 영향을 미치는 것으로 보인다. Table 1에서 나타난 바와 같이, 알코올 함량, 휘발산 함량이 다른 처리구에 비해서 낮고 아미노산도도 그리 높지 않은 약주의 품질 특성이 선호하는 맛과 관련이 있을 것이라고 추측한다. 냉동후 처리한 연잎을 사용한 약주(B)에서는 색 은 덖음처리구가 가장 높은 수치를 나타냈고 향이나 맛, 전반적인 기호도에서는 데치기 처리구에서 가장 높은 수치 를 나타냈다. 특히 색에 있어서 덖음 처리가 선택율 $50 \%$ 로 높게 나타났는데 이것은 Table 2에서 보여 지는 바와 같이 높은 폴리페놀 함량과 이로 인한 $\mathrm{a}$ 값, $\mathrm{b}$ 값과 관련이 있을 거라고 추측한다. 맛에 있어서는 냉동전 처리 약주와 마찬 가지 결과로 Table 1 에서 보는 바와 같이 알코올함량, 휘발 산 함량, 아미노산도와 관련이 있을 거라고 사료된다.

\section{요 약}

연잎으로 제조한 약주의 연중 생산을 위한 원료의 효과 적인 전처리 방법에 대하여 알아보기 위해 냉동 전 - 후로 처리를 달리한 연잎을 사용한 연잎약주의 품질특성을 조사 하였다. 냉동 전 후로 처리한 연잎약주에서 총산함량을 제외하고 $\mathrm{pH}$, 아미노산도, 알코올, 휘발산 함량에서 처리구 간의 유의적인 차이를 나타냈다. 폴리페놀 함량은 전체적 
으로 $315.89 \pm 28.08 \sim 462.63 \pm 13.00 \mathrm{ppm}$ 의 범위였고 모든 처 리구간에 유의적인 차이를 보였다. 특히, 냉동전 덖음 처리 약주에서 $462.63 \pm 13.00 \mathrm{ppm}$ 으로 높은 수치를 보였다. 약주 의 색도에 있어서는 L값의 경우 모든 처리구에서 유의적인 차이를 보이지 않았고, 적색도를 나타내는 $\mathrm{a}$ 값은 냉동 후 처리한 약주에서 유의적인 차이를 보이지 않았고 냉동전 처리한 약주에서는 유의적인 차이를 보였다. 황색도를 나 타내는 $\mathrm{b}$ 값에서는 냉동 전 · 후 데치기 처리에서 가장 낮은 값을 보였고 모든 처리구간에 유의적인 차이를 보였다. 연 잎 약주의 유기산 중에서 주석산(tartaric acid)과 호박산 (succinic acid)은 모든 처리구간에 유의적인 차이가 없었으 며 옥살산(oxalic acid), 구연산(citric acid), 사과산(malic acid) 함량은 처리구에 따라 다른 양상을 보였다. 냉동전 처리한 연잎 약주의 기호성 평가 결과, 냉동전 처리 연잎약 주의 경우, 색과 향에 있어서 생잎과 건조처리구의 선호도 가 높게 나타났다. 반면, 색에 있어서 덖음처리(10\%)와 향 에 있어서 데치기 처리(15\%)가 낮은 선택율을 보였다. 향에 있어서는 생잎이나 건조 처리구 약주에서 더 선호하는 것으 로 나타났다. 맛이나 전반적인 기호도에 있어서는 색과 향 기의 결과와는 다르게, 데치기 처리가 높은 선택비율(40\%) 을 보였는데 약주의 전반적인 기호도는 색과 향기보다는 맛이 크게 영향을 미치는 것으로 보인다. 냉동후 처리한 연잎을 사용한 약주에서는 색은 덖음처리구가 가장 높은 수치를 나타냈고 향이나 맛, 전반적인 기호도에서는 데치 기 처리구에서 가장 높은 수치를 나타냈다.

\section{감사의 글}

본 연구는 국립농업과학원 농업과학기술 연구개발사업 (과제번호: PJ01007401)의 지원에 의해 이루어진 것이며, 연구비 지원에 감사드립니다.

\section{References}

1. Lee JY, Kwak EJ (2009) Fermentation characteristics of grape Yakju made with three kinds of grape. J East Asian Soc Dietary Life, 19, 96-104

2. Kim MJ, Kim BH, Han JK, Lee SY, Kim KS (2011) Analysis of quality properties and fermentative microbial profiles of takju and Yakju brewed with or without steaming process. J Fd Hyg Safety, 26, 64-69

3. Cho KS, Jeong EY, Choi HS, Kim MK (2012) Brewing and quality characteristics of Schisandra chinensis Yakju. J Appl Biol Chem, 55, 163-167

4. Jin TY, Kim ES, Eun JB, Wang SJ, Wang MH (2007)
Changes in physicochemical and sensory characteristics of rice wine, Yakju prepared with different amount of red yeast rice. Korean J Food Sci Technol, 39, 309-314

5. Kim OS, Choi OJ, Shim KH (2012) Effect of pretreatment on the physicochemical properties of lotus root powder. Korean J Food Preserv, 19, 74-80

6. Yang HC, Heo NC, Choi KC, Ahn YJ (2007) Nutritional composition of white-flowered and pink-flowered lotus in different parts. Korean J Food Sci Technol, 39, 14-19

7. Yoo HN, Chung CH (2011) Fermentation characteristics of takju prepared with lotus leaf. Korean J Food Cook Sci, 27, 577-587

8. Lee HK, Choi YM, Noh DO, Suh HJ (2005) Antioxidant effect of korean traditional lotus liquor (Yunyupju). International Journal of Food Science and Technology, 40, 709-715

9. Lee KS, Kwon YJ, Lee KY (2008) Analysis of chemical composition, vitamin, mineral and antioxidative effect of the lotus leaf. J Korean Soc Food Sci Nutr, 37, 1622-1626

10. Lee KS, Lee KY (2011) Effect of lotus (Nelumbo nucifera) leaf extract on serum and liver lipid levels of rats fed a high fat diet. Korean Soc Food Sci Nutr, 40, 1544-1547

11. Shin MK, Han SH (2006) Effects of lotus (Nelumbo nucifera Gaertner) leaf powder on lipid concentrations in rats fed high fat diet rats. Korean J Food Culture, 21, 202-208

12. Lee KS, Oh CS, Lee KY (2006) Antimicrobial Effect of the fractions extracted from a lotus (Nelumbo nucifera) leaf. J Korean Soc Food Sci Nutr, 35, 219-223

13. Park BH, Jeon ER, Kim SD, Cho HS (2010) Quality characteristics of dried noodle added with lotus leaf powder. Korean J Food Culture, 25, 225-231

14. Han KY, Yoon SJ (2007) Quality characteristics of lotus leaf jeolpyun during storage. J Korean Soc Food Sci Nutr, 36, 1604-1611

15. Jeong CS, Um GJ, Park JN (2010) Changes of storage temperatures on the physiological characteristics in leafy vegetables. J Agric Life Sci, 22, 33-41

16. Lee YJ, Lee HO, Kim JY, Kwon KH, Cha HS, Kim BS (2011) Quality characteristics of frozen Doraji (Platycodon grandiflorum) according to various blanching treatment conditions. Korean J Food Preserv, $18,661-668$

17. Choi HD, Koh YJ, Kim YS, Choi IW, Cha DS (2007) Changes in physiochemical and sensory characteristics of dandelion (Taraxacum officinale) leaves by roasting 
treatment. Korean J Food Sci Technol, 39, 515-520

18. Kim DC, Kim DW, In MJ (2006) Preparation of lotus leaves tea and its quality characteristics. J Korean Soc Appl Biol Chem, 49, 163-164

19. Lee BS, Lee WY (2010) Changes in the chemical composition of apple slices pretreated with supercritical carbon dioxide. Korean J Food Preserv, 17, 256-260

20. National Tax Service Liquors Licence Aid Center (2009) Liquor analysis code, Korea, p 42

21. Chang EH, Jeong ST, Roh JH, Jeong SM, Lee HC, Choi JU (2010) Wine quality properties with reference to the temperature of grape-must prior to fermentation. Korean J Food Preserv, 17, 608-615

22. Jung SM, Chang EH, Park SJ, Jeong ST, Roh JH, Hur YY Lee HC (2010) Berry thinning effects on the fruit and wine quality of grape 'Muscat Bailey A'. Korean J Food Preserv, 17, 625-630

23. Song YR, Lim BU, Song GS, Baik SH (2015) Quality characteristics and antioxidant activity of Makgeolli supplemented with Omija berries (Schizandra Chinensis Baillon). Korean J Food Sci Technol, 47, 328-335
24. Chun AR, Kim DJ, Yoon MR, Oh SK, Choi IS, Hong HC, Kim YG (2012) Effect of milling degree on the physicochemical and sensory quality of Sogokju. J Korean Soc Food Sci Nutr, 41, 136-142

25. Kang JE (2013) Manual of Fermented Food Properties, National Institute of Agricultural Science, Department of Agro-Food Resorces, Wanju, Korea, p 27

26. Lee KS, Kwon YJ, Lee KY (2008) Analysis of chemical composition, vitamin, mineral and antioxidative effect of the lotus leaf. J Korean Soc Food Sci Nutr, 37, 1622-1626

27. Kong MH, Yeo SH, Choi JH, Choi HS, Jeong ST (2011) Characteristics of the Yakju fermented with differently-processed lotus leaves. J East Asian Soc Dietary Life, 21, 911-917

28. Lee HK, Choi YM, Noh DO, Suh HJ (2005) Antioxidant effect of korean traditional lotus liquor (Yunyupju). Int J Food Sci Technol, 40, 709-715

29. Noh JM, Kang JE, Choi JH, Jeong ST, Choi HS (2014) Changes in physiochemical properties of Yakju prepared by accelerated aging without protease. Korean J Food Sci Technol, 46, 702-709 